\title{
Exploring the Apostleship of Prayer Collection at the Archivum Romanum Societatis Iesu (ARSI): Between Archival Analysis and Research Perspectives
}

Author: Sergio Palagiano

Source: Engaging Sources: The Tradition and Future of Collecting History in the Society of Jesus (Proceedings of the Symposium held at Boston College, June 11-13, 2019)

Edited by: Cristiano Casalini, Emanuele Colombo, and Seth Meehan

ISBN: 978-1-947617-09-4

Published by: Institute of Jesuit Sources

Originally Published: March 1, 2021

https://doi.org/10.51238/ISJS.2019.32

Provided in Open Access by the Institute for Advanced Jesuit Studies at Boston College.

The Institute of Jesuit Sources, specializes in preserving, maintaining, and expanding for scholars around the world important texts and studies in Jesuit history, spirituality, and pedagogy.

Visit our website at https://jesuitsources.bc.edu 


\title{
Exploring the Apostleship of Prayer Collection at the Archivum Romanum Societatis Iesu (ARSI): Between Archival Analysis and Research Perspectives
}

\author{
SERGio PALAGIANO
}

The Apostleship of Prayer Collection, kept by the ARSI, constitutes a highly valuable source for research on several different topics: from the cult and devotion to the Sacred Heart to the Society's relationship with its own works and those founded by the Jesuits; and from the use of mass media as a tool to spread the Catholic faith to the history of Catholic associations. This essay is structured in three parts. First, it provides a historical profile of the association. The second part is dedicated to the archival collection itself and to its framework, with a few remarks on its content and the typology of the documents. The last part contains some examples of research lines that could benefit from the documentation contained in the collection.

The Apostleship of Prayer Collection comprises documentation related to the homonymous association founded by François-Xavier Gautrelet, a Jesuit priest, on December 3, 1844 in the Jesuit seminary of Vals-près-le-Puy (Haute Loire, France). In 1846, the association obtained the protection of Mgr. Pierre Darcimoles, the bishop of Le Puy, but it was only under his successor, Mgr. Joseph Morlhon, that it was given a canonical order. ${ }^{1}$

The association's initial goal was to care for the spirituality of the Society's seminarists and academics, but eventually its renown grew among ecclesiastical and lay members as well. It used prayers as a means to spread Catholicism and promote zeal and charity. By performing three devotional practices, the association's members made three different commitments: they committed their daily prayers, actions, joys, and sufferings to the Sacred Heart; they committed their life to the Sacred Heart; and they committed to the Oeuvre de la Communion Réparatrice (Reparative Communion Work), an autonomous association that later merged with the Apostolate of Prayer. The spiritual baseline adopted since the very foundation was the one outlined by St. Margaret Mary Alacoque of the Order of the Visitation of Holy Mary in Paray-le-Monial and her confessor, St. Claude de la Colombière.

\footnotetext{
${ }^{1}$ Archivum Romanum Societatis Iesu (henceforth ARSI), Apostleship of Prayer (henceforth AoP), Ancient Section, Archives de l'enregistrement constitutionnel et canonique, 13, 15. 
The Apostleship of Prayer became a stalwart champion of the cult of and devotion to the Sacred Heart, as it was both a prominent part of its theological foundation and one of its devotional practices. In this respect, the correspondence between Gautrelet and Jan Philip Roothaan, superior general of the Society of Jesus between 1829 and 1853, is of particular interest (see fig. 1).

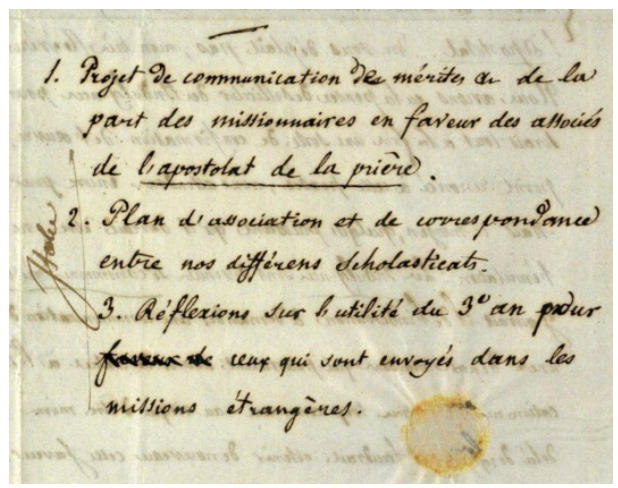

Figure 1. Fr. Gautrelet to Fr. Roothaan, January 11, 1847. ARSI, AoP, Ancient Section, Institutum, 40, I, 1.

On June 8, 1848 and July 24, 1848, Roothaan issued two letters to all Jesuits under the respective titles of "About the Cult of and Devotion to the Sacred Heart of Jesus" and "About the Cult of and Devotion to the Most Pure Heart of Mary" (fig. 2).

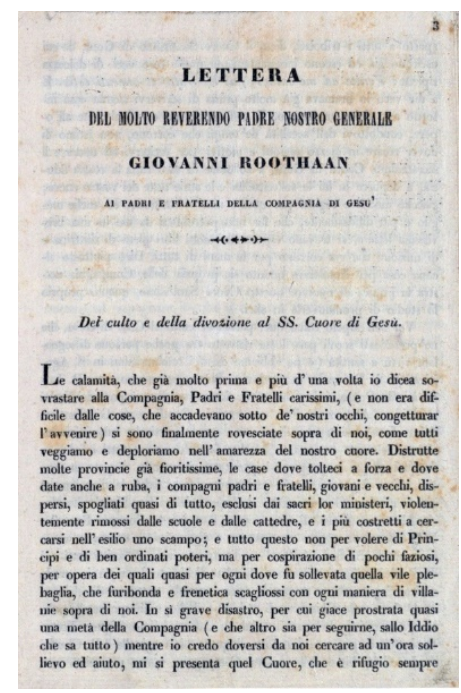

Figure 2. Circular letter, June 8, 1848. ARSI, AoP, Ancient Section, Institutum, 41, I, 1.

Some 175 years after its founding, the association remains very active through a series of different movements, such as the Eucharistic Youth Movement. Its seat is located in Rome, and its historical archive is kept at ARSI. On March 27, 2018, 
Pope Francis (r.2013-) approved its new statute with the name of Pope's Worldwide Prayer Network (Apostleship of Prayer). The association became a pontifical work, whose defined mission was to pray and encounter the challenges facing humanity and the mission of the Catholic Church that concern the pope as expressed in his monthly intentions. The association, though, has enjoyed the pope's stated support since its origin, as demonstrated by the indulgences different pontiffs granted it (fig. 3). ${ }^{2}$

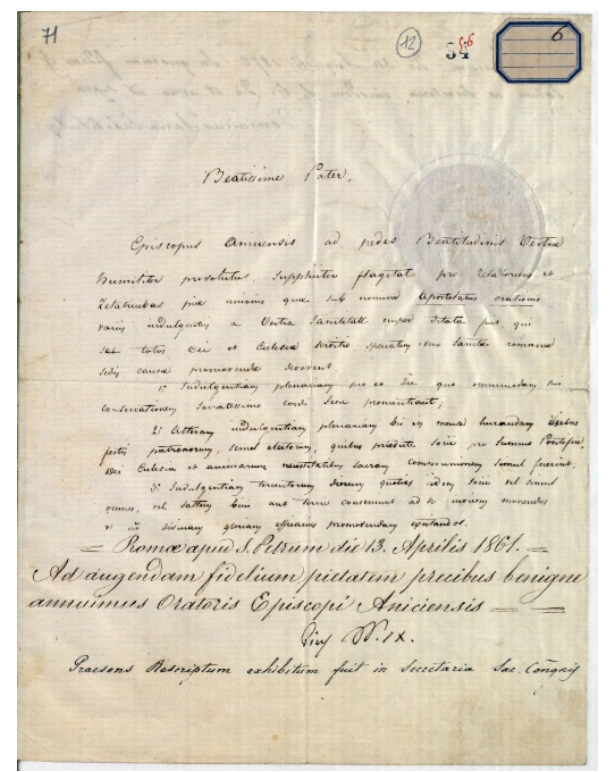

Figure 3. Indulgence, April 13, 1861. ARSI, AoP, Ancient Section, Archives de l'enregistrement constitutionnel et canonique, 13, 12.

From 1874 to 1892 , additional support was received from its two cardinals protectors, two prefects of the Congregation de Propaganda Fide, Cardinals Alessandro Franchi (in office 1874-78) and Giovanni Simeoni (in office 1878-92). ${ }^{3}$

The year 1861 marked a turning point in the association's history. In that November, Gautrelet, after serving as rector of the Domus Tertiae Probationis (House of the Third Probation) in Lyon (1855-57) and superior of the Provincia Lugdunensis (1857-61), was appointed superior of the Missio in Africa by the new provincial and sent to Algiers. His successor as the director of the Apostleship of Prayer was Henri Ramière, who had been Gautrelet's assistant for the previous two years. ${ }^{4}$ Under Ramière (fig. 4), the Apostleship gained new momentum.

\footnotetext{
${ }^{2}$ ARSI, AoP, Ancient Section, Archives de l'enregistrement constitutionnel et canonique, 13, 4-5; see also Provincia Lugdunensis 1003, XXVI, Index, and Provincia Romana 1029, XIII, 27.

${ }^{3}$ ARSI, AoP, Ancient Section, Acta Apostolatus Orationis, 8 and 12; Institutum, 40, VI-VII; Dossiers, Dossier D. De Consecratione Familiarum.

${ }^{4}$ ARSI, Provincia Lugdunensis 1001, XX, Index.
} 


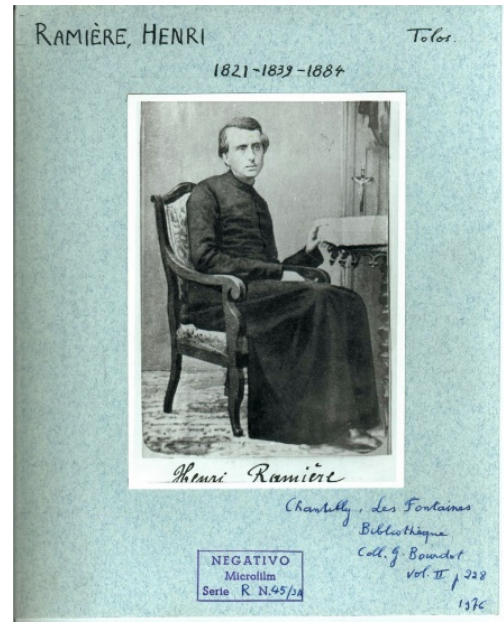

Figure 4. Fr. Henri Ramière. ARSI, Fototeca.

The key factor in its ensuing widespread diffusion throughout the world was Le messager du Sacré Cour de Jésus's bulletin mensuel de l'Apostolat de la prière (The messenger of the Sacred Heart of Jesus: A monthly bulletin of the Apostleship of Prayer), a periodical published from 1861 that was later flanked by Le petit messager du Cour de Marie (The little messenger of the Heart of Mary) (fig. 5).

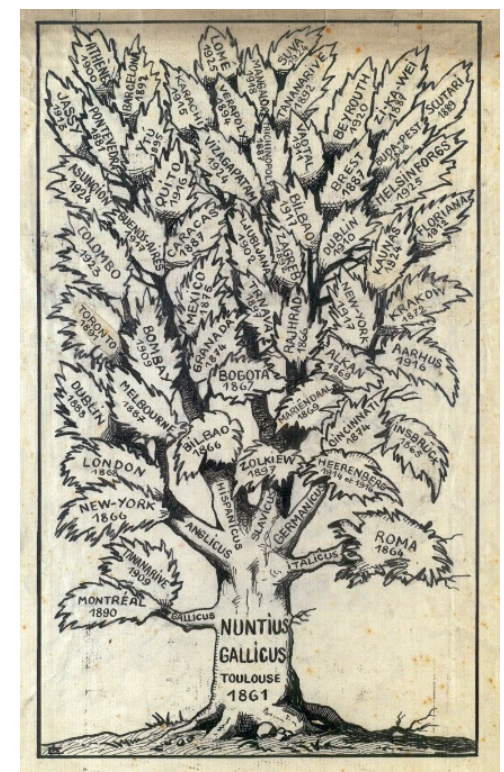

Figure 5. Messager tree. post 1925. ARSI, AoP, Iconographic Section, Manifesti, 1.

During the following decades, the association's influence throughout the world spread very quickly, requiring regular modifications of its structure and rules to simplify the administration process in view of the growing challenges while also making it more adaptable to different linguistic, social, and cultural contexts. The 
oldest statute available in the archival collection is one approved by Mgr. Pierre Le Breton, the bishop of Le Puy between 1863 and 1886. The document dates back to a period between September 1863 (at the beginning of Le Breton's career as bishop) and September 12, 1866 (when the Congregation of Bishops and Regulars approved the new statute). In 1879, yet another statute was approved. Its final form was ultimately authorized in 1896 (fig. 6), providing a structure that, not including a few modifications introduced in April 1925, continued to regulate the organization until the $1950 \mathrm{~s}^{5}$

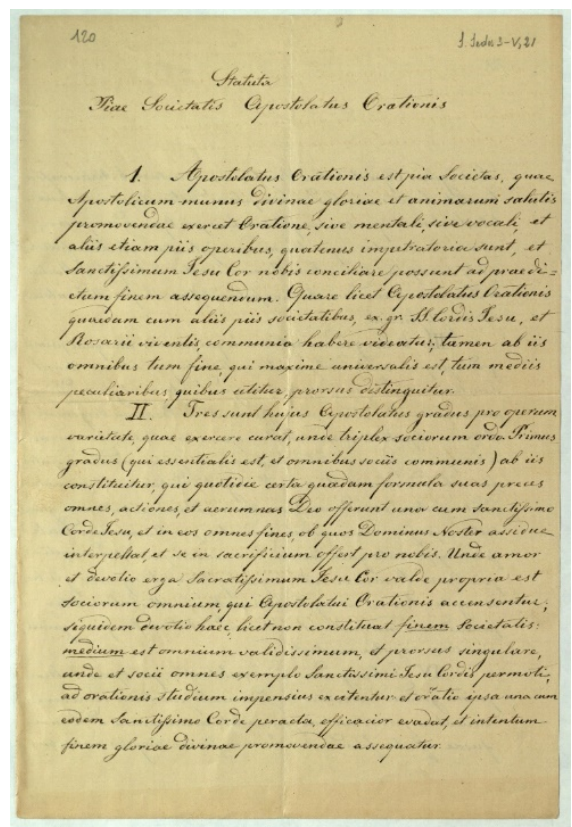

Figure 6. Statute, July 11, 1896. ARSI, S. Sede, Diplomata, 1003, V, 21.

The association had a pyramid structure with local centers (parishes and others) at the base. These centers were coordinated by diocesan directorates that followed the instructions given by the national offices. At the top of this pyramid was the Directorate General led by a general director who was appointed directly by the superior general of the Society of Jesus until 1896. The modification of the statute of 1896 shifted this role to the hands of the superior general himself, who would in turn appoint a delegate. The seat of the association moved several times based on logistical and other concerns. In 1868, the headquarters were relocated from Le Puy-enVelay to Toulouse before moving again to Tournai in Belgium in 1904, an event known to all Jesuits as the Residentia Tolosana dispersa: in 1880, the Society was in fact expelled from France. The seat moved back to Toulouse only in 1914, where

\footnotetext{
${ }^{5}$ ARSI, AoP, Ancient Section, Archives de l'enregistrement constitutionnel et canonique, 13:10,
} 16, 43; 14 : 10, 20, 21; Institutum, 40 VI, 3; Institutum, 42, III, 10; Dossiers, Dossier C. De Statutis. 
it stayed until July 1925 when Superior General Włodzimierz Ledóchowski (in office 1915-42) decided to relocate it to Rome, inside the newly acquired seat of the Jesuit curia, even though the relocation was only completed in April $1927 .^{6}$

\section{The Archives}

The arrangement and analytical inventorying of the archive was carried out between 2017 and 2018. The fund comprises three separate sections (ancient, modern, and iconographic) and numbers around two thousand archival units encompassing the period from 1847 until 1969, with documents since 1813. Ultimately, more than five thousand indexed entries have been identified and divided into the categories of institutions, individuals, toponyms, and other.

The Ancient Section contains the following archival series:

1. Registers of Aggregation of Local Centers (1861-1950);

2. Registers of Diocesan Directors (1871-1968);

3. Archives de l'enregistrement constitutionnel et canonique (Constitutional and canonical registration archives [1849-1961]), also with Échange et communication de mérites des sociétés religieuses (Exchange and communication of merits of religious societies [18631961]);

4. Acta Apostolatus Orationis (Documents of the Apostleship of Prayer [1849-1962]);

5. Institutum (Institute [1847-1921]);

6. Dossiers (1866-1969);

7. Roman Brotherhood of the Sacred Heart of Jesus (1864-1911);

8. Oeuvre de la Communion Réparatrice (1861-93).

The series "Registers of Aggregation of Local Centers" consists of registers divided according to the alphabetical order of dioceses, parishes, and religious communities aggregated to the Apostleship of Prayer, with the indication of the date of aggregation.

The series "Archives de l'enregistrement constitutionnel et canonique" includes the association's constitutional documents and the different statutes, briefs, and decrees for the granting of indulgences. One set of documents of particular interest is "Échange et communication de mérites des sociétés religieuses," including the certificates "...omnium privilegiorum, indulgentiarum, sacrificiorum, precum, disciplinarum, peregrinationum, piorum operum, aliorumque quorumvis bonorum spiritualium [...]" (Of all privileges, indulgences, sacrifices, prayers, disciplines, peregrinations, pious works, and any other spiritual good) issued by the

\footnotetext{
${ }^{6}$ ARSI, AoP, Ancient Section, Acta Apostolatus Orationis, 3, 55; 4, 51; 7, 58.
} 
Apostleship of Prayer to several religious and laic orders, congregations, and institutions, which were appointed as effective heirs of the spiritual tradition of the Apostleship itself. The collections in this series testify to the extensive spiritual exchange between the Apostleship and the vast number of both laic and religious congregations. Since its origins, the Apostleship took into account different types of Catholic congregations. A memo dated 1852, for example, reads:

In Piedmont, an analogous association was soon formed under the name of Sanctified Universe, Orbe Sanctificato, and these movements soon extended like an electric shock to the heart of Christendom. D. Vincenzo Pallotti, who has since died in the odor of holiness, founded a few near Rome under the name of Catholic Apostolate, a pious association [... . $^{7}$

The Apostleship also had close connections on different levels with many other Catholic associations, such as the Roman Brotherhood of the Sacred Heart of Jesus, the Oeuvre de la Communion Réparatrice, the Catechism of Perseverance, the Living Rosary, the Holy Hour, the Milice du Pape (Militia of the Pope), the Association des Zèlatrices du Cœur de Jésus et du Cœur Immaculé de Marie in Toulouse (Association of Zealots of the Heart of Jesus and the Immaculate Heart of Mary) (whose 1852 statute is in the Apostleship of Prayer collection), the Little Family of the Sacred Heart (the first documented case of a non-religious group of worshippers of the Sacred Heart that sought to lead a community life), and the Pious Union of the Worshippers of the Sacred Heart of Jesus of Mondovì in Italy.

The series "Acta Apostolatus Orationis" includes several documents related to the connections between the Eucharistic Crusade of the Apostleship of Prayer and the analogue institution founded by the Order of Canons Regular of Prémontré (the Premonstratensians) in the Belgian abbey of Averbode. It also contains documents on the relations between the company and the Apostleship of Prayer and between the Congregation of the Sacred Hearts of Jesus and Mary (of Picpus) and the work of the Enthronement of the Sacred Heart of Jesus in families founded and promoted by Fr. Mateo Crawley-Boevey. Another rather interesting piece of documentation is the testimony regarding St. Caterina Volpicelli, the founder of the Handmaids of the Sacred Heart, and Louise Thérèse de Montaignac de Chauvance, first general secretary of the Apostleship of Prayer and founder of the Pieuse Union

\footnotetext{
${ }^{7}$ En Piémont une association analogue se forma bientôt sous le nom d'Univers Sanctifié, Orbe Sanctificato, et ces mouvements se prolongeant bientôt comme une commotion électrique jusqu'au Cour de la Chrétienté, D. Vincenzo Pallotti mort depuis en odeur de sainteté fonda peus à pres à Rome sous le nom d'Apostolat Catholique une pieuse association [...]; ARSI, AoP, Ancient Section, Archives de l'enregistrement constitutionnel et canonique, 13, 7-9 (Bref de Mondovì sur des 9 Offices. Les 9 Offices du Cœur de Jésus. Indulgences accordées aux Fidèles du Diocèse de Mondovì Piémont 1856).
} 
des Oblates du Sacré Cœur (Pious Union of the Oblates of the Sacred Heart). Both the series "Acta" and "Institutum" also comprise the correspondence of the Society with members of the Barnabites (Clerics Regular of Saint Paul), the religious order that in 1879 was appointed by the superior general of the Society, Pieter Jan Beckx (in office 1853-87), to direct the Italian office of the Apostleship. It was only in 1917 that the direction of said office returned to the Society of Jesus.

Like the "Archives de l'enregistrement constitutionnel et canonique" and "Acta Apostolatus Orationis" series, the "Institutum" series contains documents establishing the Apostleship of Prayer, as well as other materials from 1847 to 1921. The series also contains the correspondence between the directors general of the Apostleship of Prayer, the superior generals of the Society, and the superior general's regional assistants.

Regarding the "Dossiers" series, the original titles of the folders are the following: De intentionibus (Prayer intentions), De indulgentiis (Indulgences), De statutis (Statutes), De consecratione familiarum (Congregation of families to the Sacred Heart), De festo Christi_Regis (Feast of Christ the King), De opere scutorum Regina Coeli (Work of the shields of the Queen of Heaven), the Anglican Church, the Messenger of the Catholic League, the Bulletin of the Confraternity of Unity, the Church Unity Octave, [Die] Opferseelen [des göttlichen Herzens Jesu] (M. Schmid) (The sacrificial souls of the divine Heart of Jesus), Garde d'Honneur [du Sacré Cœur] (Guard of honor of the Sacred Heart), Enquête 1899 (Investigation 1899), and Sur l'Archiconfrérie de Montmartre (About the archconfraternity of Montmartre). The Dossiers contain original documents about the monthly prayer intentions proposed to the pope. Each proposal has the related corrections, deletions, and signature of the pope. Based on the changes made to the proposal, it is possible to infer the reasons and the circumstances that led to the exclusion of some intentions (fig. 7). 


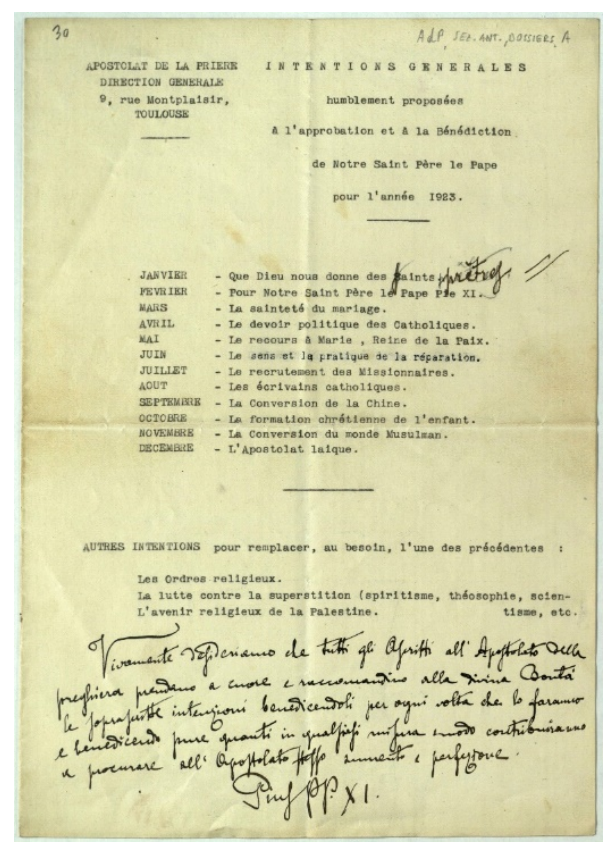

Figure 7. Prayer intentions, 1923. ARSI, AoP, Ancient Section, Dossiers, Dossier A. De Intentionibus, 1, 30.

Among other documents, those witnessing the controversy between the Apostleship, the Congregation of the Sacred Hearts of Jesus and Mary (the Picpus Fathers), and Crawley-Boevey's organization of the Family Enthronement of the Sacred Heart of Jesus stand out as particularly noteworthy. The controversy ended only in 1923 through the effort of a special commission of cardinals specifically convened to solve this matter. ${ }^{8}$ The series also contains a collection of documents regarding the women's section of Catholic Action, chaired, first, by Cristina Giustiniani Bandini and then by Maddalena Patrizi Gondi, who were given the task of spreading the association's influence in Italy.

The series "Oeuvre de la Communion Réparatrice" holds the documentation related to the organization born as an independent movement and later annexed within the Apostleship of Prayer. The Oeuvre was founded by Victor Drevon at the Monastery of the Visitation in Paray-le-Monial, though all the directors of the Apostleship of Prayer were by right also entrusted with the guidance of the Oeuvre. The work was enriched with numerous indulgences from 1861. On July 2, 1865, the Monastery of the Visitation of Paray-le-Monial was established as the seat and spiritual center of the Oeuvre, with Drevon being appointed its general director. Upon Drevon's death in March 1880, the direction of the work was entrusted to the general director of the Apostleship of Prayer, with the simultaneous transfer of the

\footnotetext{
${ }^{8}$ ARSI, AoP, Ancient Section, Acta Apostolatus Orationis, 9, 24.
} 
seat to that of the Apostleship in Toulouse. In 1893, Emile Trouiller tried, unsuccessfully, to restore the Oeuvre's autonomy from the Apostleship of Prayer. ${ }^{9}$

The Modern Section contains the following archival series:

1. Correspondence with the National Secretariats (1882-1949);

2. Eucharistic Crusade (1890-1960);

3. International Eucharistic Congresses (1908-1940).

The collection is divided geographically and bears witness to the many activities the Apostleship conducted in all the countries in which it was present (fig. 8).

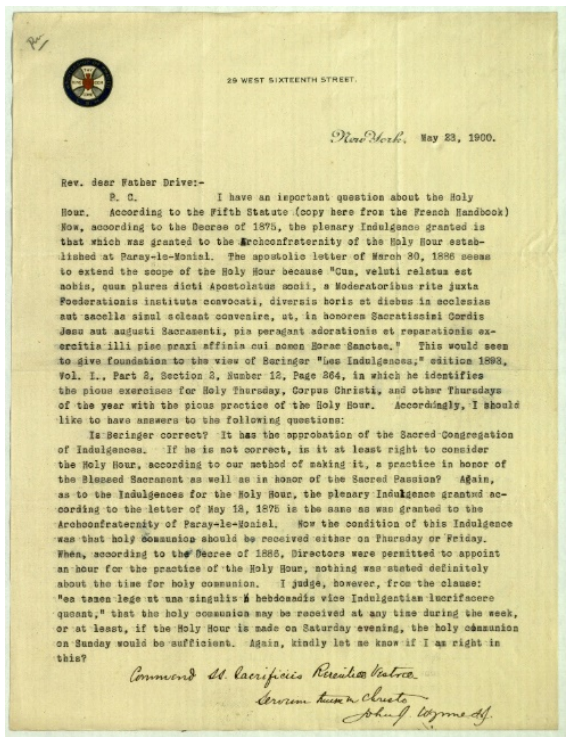

Figure 8. Fr. John J. Wynne, S.J. to Fr. Auguste Drive, S.J., May 23, 1900. ARSI, AoP, Modern Section, Correspondence with the National Secretariats, 44, 354.

The titles of the forty-eight folders are in alphabetical order, from Aegyptus to Venezuela. This set of documents has general information and surveys related to each national center's foundation, its organizational chart, its operation, and its activities, including any publications and the number of subscribers. The archival structure also reveals how capillary the diffusion of the Apostleship was throughout the world, a diffusion that depended on the translation of bulletins and other informative material into several different languages (fig. 9).

\footnotetext{
${ }^{9}$ ARSI, AoP, Ancient Section, Oeuvre de la Communion Réparatrice, 11.
} 


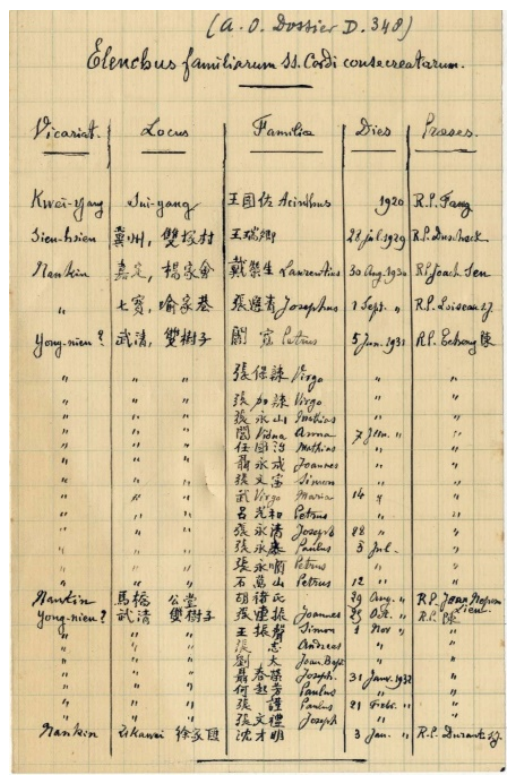

Figure 9. Chinese families consecrated to the Sacred Heart, post 1932. ARSI, AoP, Ancient Section, Dossiers, Dossier D. De Consecratione Familiarum, 2, 348.

The establishment of the Eucharistic Crusade movement was decided during the International Eucharistic Congress of Lourdes in 1914, yet already at the Congress of Antwerp in 1890 it was declared that “...l'Apostolat de la Prière est une Croisade Eucharistique permanente [...]" (The Apostleship of Prayer is a permanent Eucharistic Crusade). This section of the archival collection includes the Series Chronologica (1917-41, with documents from 1890) and Dossiers (1919-57, with documents from 1900), relating to specific affairs. The first series includes the epistolary exchange between the general secretary of the Crusade and the Apostleship's national promoters. The Dossiers series contains documentation concerning the Crusade at the Averbode Abbey, the Milice du Pape, the Pages of the Most Holy Sacrament, and the association of the Knights and Handmaids of the Blessed Sacrament, among others.

The series "International Eucharistic Congress" comprises the documentation produced and collected by Joseph Boubée, who held the offices of both the general delegate of the Apostleship of Prayer and the Standing Committee consultor for the International Eucharistic Congress. The series contains documentation related to the International Eucharistic Congress of London 1908, Vienna 1912, Lourdes 1914, Rome 1922, Amsterdam 1924, Chicago 1926, Sydney 1928, Tunis 1930, Dublin 1932, Buenos Aires 1934, Manila 1937 (fig. 10), Budapest 1938, and Barcelona 1952. 


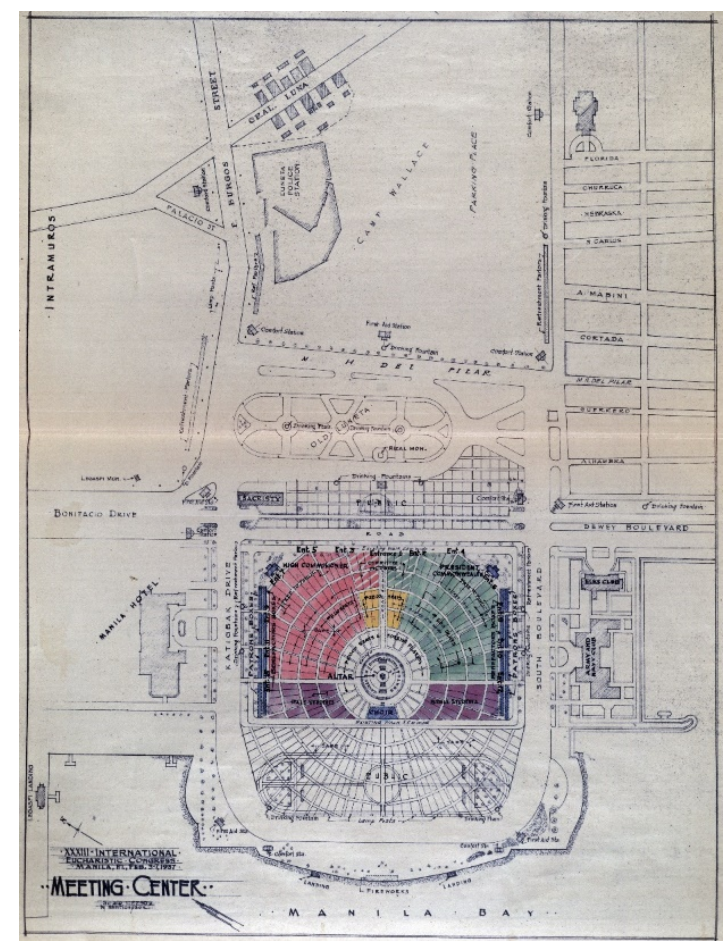

Figure 10. Thirty-Third International Eucharistic Congress, Project of the Meeting Center. ARSI, AoP, Modern Section, International Eucharistic Congresses, 5, 18.

The "Iconographic Section" keeps documents from 1813 to 1964 and contains the following archival series:

1. General and Missionary Monthly Prayer Intentions (1938-1960);

2. Collectio imaginum SS. Cordis Iesu et Puriss. Cordis B.M.V. (Collection of images of the Sacred Heart of Jesus and the most pure Heart of the Blessed Virgin Mary [1813-1956]);

3. Albums (1868-1947);

4. Posters (1924-60).

The first series of this section, dedicated to the general and missionary monthly prayer intentions, has 1,046 posters with illustrations and texts concerning the general and missionary intentions edited by the Apostleship's National Center of Belgium (both French-and Flemish-speaking), Spain, Mexico, Italy, and France since 1938 (figs. 11-12). 

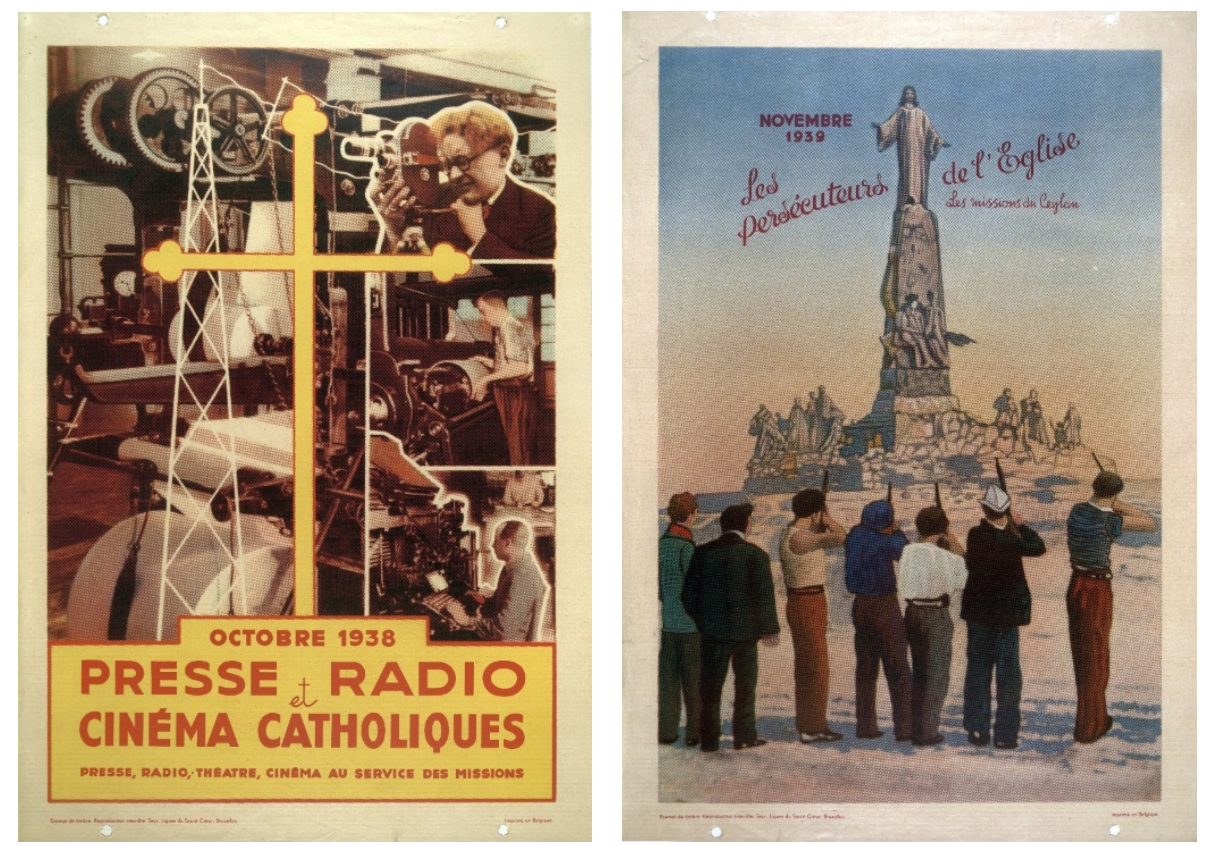

Figures 11-12. General and missionary monthly prayer intentions. Posters October 1938 and November 1939. ARSI, Iconographic Section, General and Missionary Monthly Prayer Intentions, 1, 1, 10-23.

Interestingly, the text in these intentions underwent several variations in the same language according to the different cultural context. Such changes have been observed when comparing the French and the Belgian versions or the Spanish and the Mexican versions. ${ }^{10}$ Among the represented images are those by many Catholic artists, some of whom were quite renowned, and many pictures provided by photography studios and publishing houses.

The series named "Collectio imaginum SS. Cordis Iesu et Puriss. Cordis B.M.V." includes sixteen volumes containing around seven thousand prints and photos of votive images from 1813 onward (figs. 13-15).

\footnotetext{
${ }^{10}$ The 1946 and 1948 posters were printed based on a set of maps belonging to the German Military Command, the British War Office, and the United States Army Map Service, maps used by armed forces during the Second World War.
} 

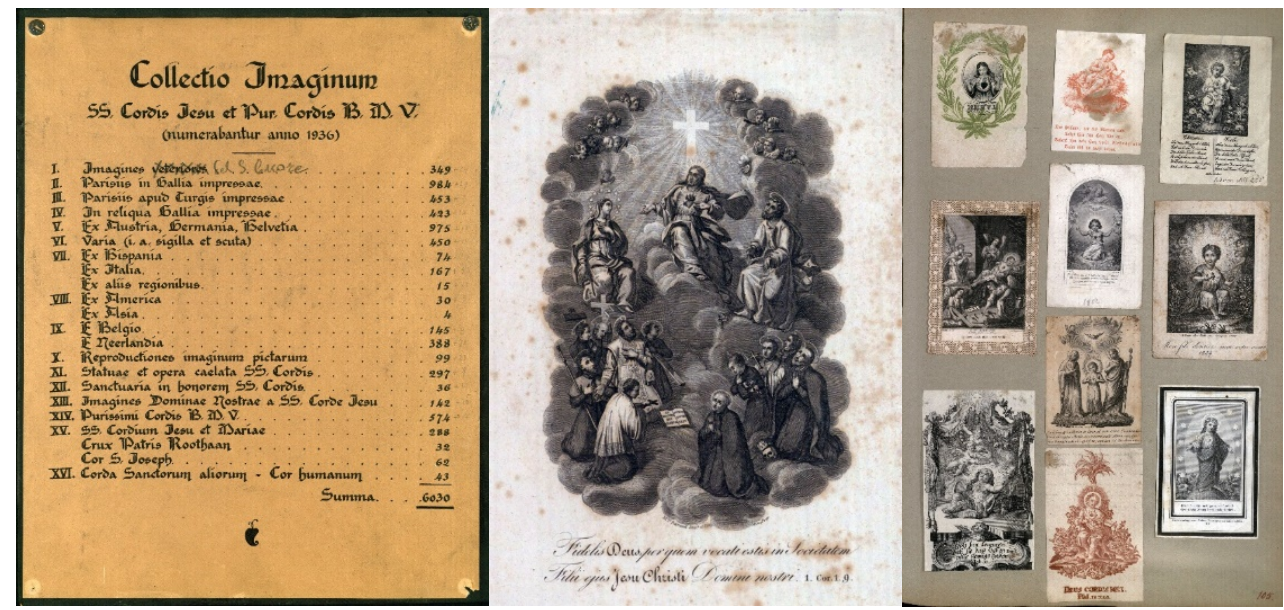

Figures 13-15. Votive images. ARSI, AoP, Iconographic Section, Collectio imaginum SS. Cordis Iesu et Puriss. Cordis B.M.V., 1, 25-56.

These volumes were anonymously collected in 1936, and the first six thousand images are divided into canivet, chromolithographs, and photomechanical reproductions. These images were updated until the first half of the 1950s. The volumes are arranged based on the type of iconography, geographical origin, and/or the editor/creators. This unique collection captures numerous representations of the Sacred Heart while also providing rarities concerning different subjects, such as the Crux Patris Roothaan or the representation of the heart of St. Joseph that was forbidden in 1879 (figs. 16-17).

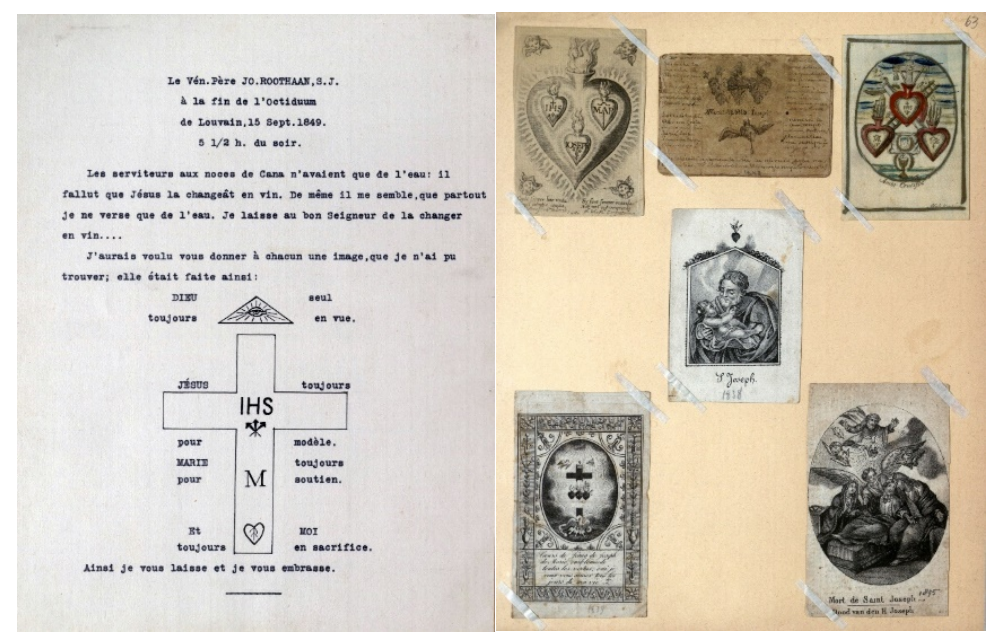

Figures 16-17. Crux Patris Roothaan; Cor S. Ioseph. ARSI, AoP, Iconographic Section, 15, 16-69. 
The two series named "Album" and "Posters" contain photographic and printed documentation related to both the Apostleship of Prayer and the Eucharistic Crusade, especially regarding congresses, meetings, conferences and other events (figs. 18-19; fig. 20).
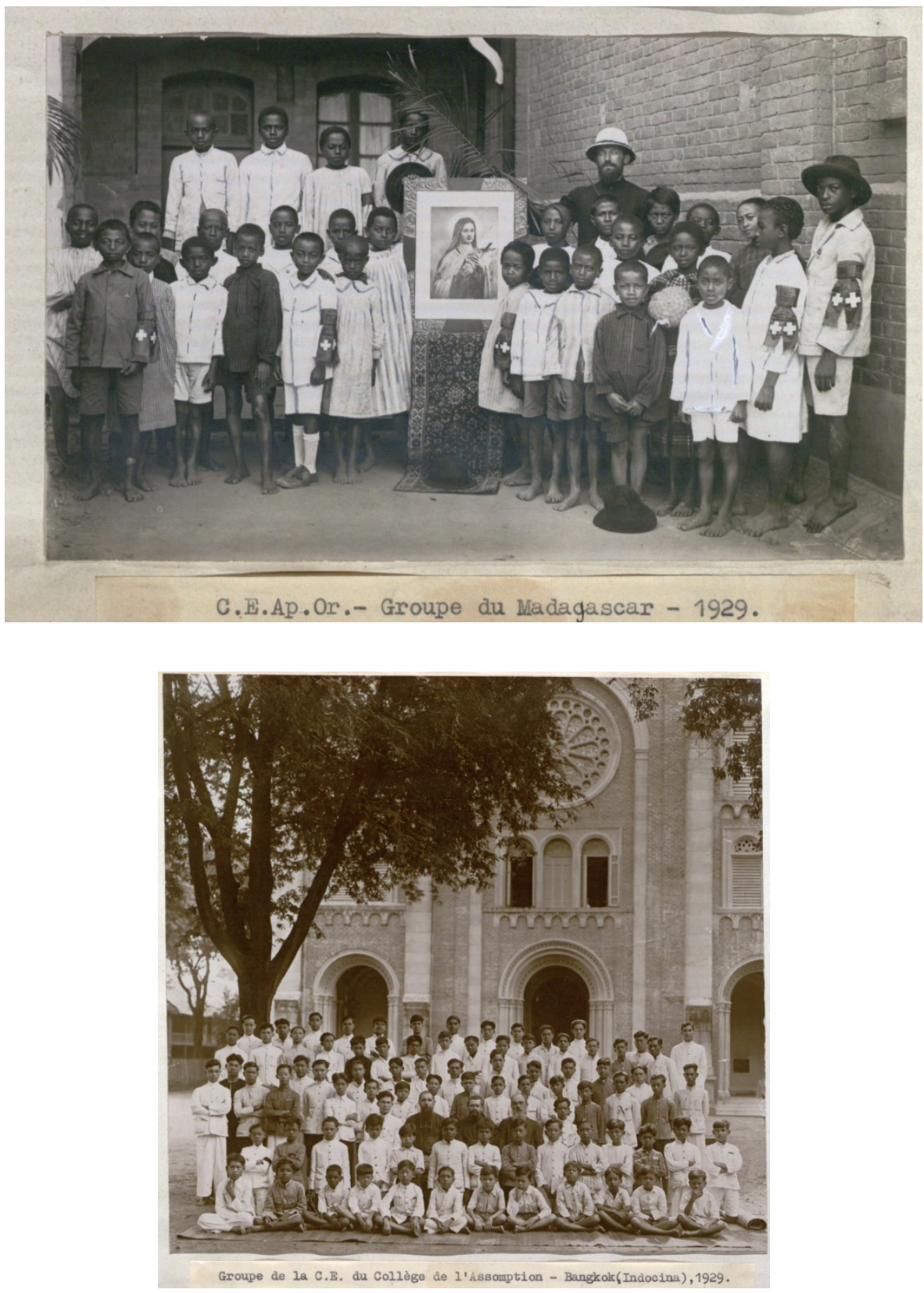

Figures 18-19. Eucharistic Crusade in Madagascar and Bangkok, 1929. ARSI, AoP, Iconographic Section, Albums, 1, 1; Posters, $2,1$. 


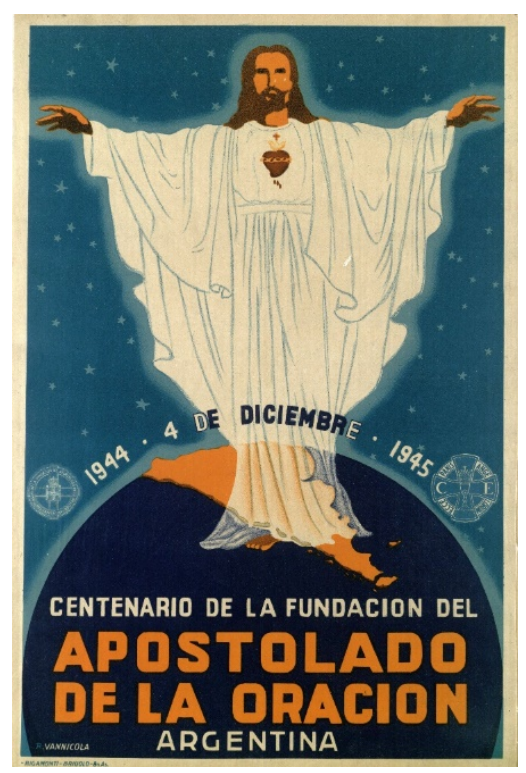

Figure 20. Centenary of the Apostolate of Prayer, Argentina 1945.

\section{Research Lines}

As the archival work drew to its end, some noteworthy research lines emerged that could benefit from the study of this archival collection. The most evident ones are:

- How and why was the association declared to be the work of the Society, though it was only founded by a Jesuit? Through this collection, one could examine an association affiliated with the Society and determine the organization's faithfulness to the Society's Constitutions and charism;

- How has the Society of Jesus worked with other religious orders and congregations to promote devotion to the Sacred Heart? This archival collection captures the relationships that the Apostleship of Prayer had with groups such as the Consecration of the Family to the Sacred Heart of Jesus, the Premonstratensian Regular Canons, and with the Barnabite Fathers;

- What were the inter-organizational relationships between the Apostleship and other Catholic associations on both a local and a global level? The documentation testifies to the relationships with several organizations (such as the Orbe Sanctificato and the Society of the Catholic Apostolate, the Roman Brotherhood of the Sacred Heart, the Oeuvre de la Communion Réparatrice) that may have been negotiated through local or global concerns;

- How did the Apostleship affect the roles played by women in the Catholic Church, such as St. Caterina Volpicelli, the founder of the Handmaids of the Sacred Heart, and Louise Thérèse de Montaignac de Chauvance, first 
general secretary of the Apostleship of Prayer and founder of the Pieuse Union des Oblates du Sacré Cœur?;

- What were the connections between the devotion to the Sacred Heart, the Apostleship, and the publishing business? (figs. 21-22).

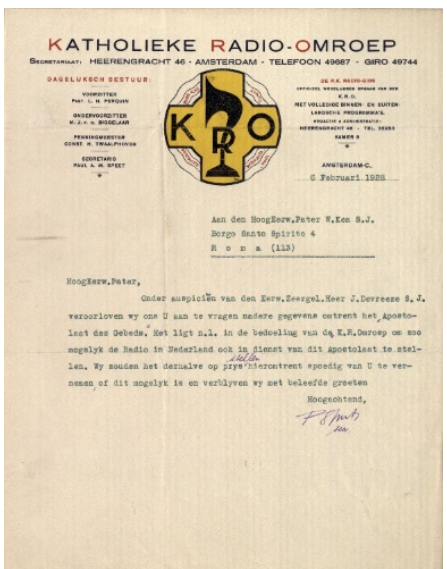

Figure 21. Paul A. M. Speet to Willem Kea, S.J., February 6, 1928.

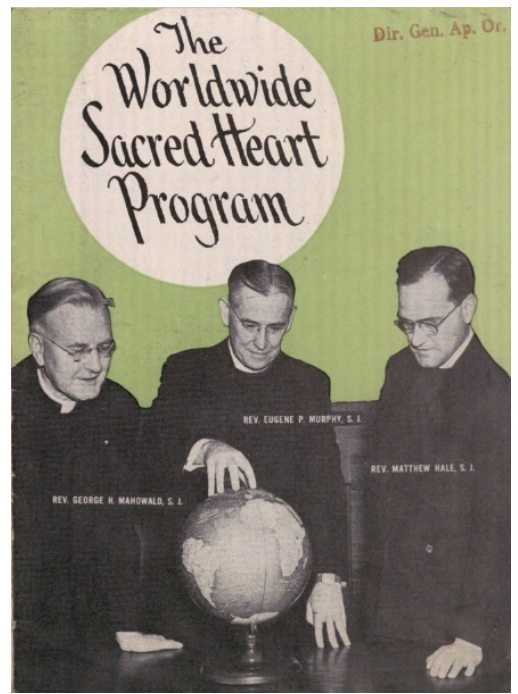

Figure 22. Publication of the Sacred Heart Program, 1939. ARSI, AoP, Modern Section, Correspondence with the National Secretariats, 36, 300; 45, 366.

The posters of the general and missionary monthly prayer intentions are sources for multidisciplinary research on what kind of criteria were used to select such illustrations, on the connections with the publishers, and on the context to which this editorial production belongs in the broader history of the means of mass communication; 
- How has devotion to the Sacred Heart and the representation of it, seen through the collection, particularly in "the Collectio imaginum SS. Cordis Iesu et Puriss. Cordis B.M.V.," changed?

\section{Conclusions}

The consistency and variety of the archival material contained in the collection will allow a multidisciplinary approach to the study of the Apostleship of Prayer, now a pontifical work: the Pope's Worldwide Prayer Network. One of the decisive factors that determine the importance of this archival fund is its global dimension. It is a network present in fifty-two countries on five continents, which today has thirty-five million Catholics in every corner of the earth. This contribution offers an overview of sources, almost all of which have yet to be studied or publishedan archival heritage still to be discovered. 


\section{Appendix}

List of Directors General and General Directors Delegates of the Apostolate of Prayer (until 1971):

1. François-Xavier Gautrelet, S.J. (December 1844-November 1861);

2. Henri Ramière, S.J. (December 1861-January 1884);

3. Emile Régnault, S.J. (January 1884-October 1894);

4. Gabriel Demartial, S.J. (October 1894-January 1895), ad interim;

5. Auguste Drive, S.J. (February 1895-March 1908), general director delegate;

6. Joseph Boubée, S.J. (March 1908-July 1911), general director delegate;

7. Jules de Lajudie, S.J. (July-September 1911), general director delegate, ad interim;

8. Joseph Calot, S.J. (October 1911-December 1924), general director delegate;

9. Joseph Boubée, S.J. (January 1925-September 1928), general director delegate;

10. Willem Kea, S.J. (September 1928-December 1930), general director delegate;

11. Jacobus Jan Zeij, S.J. (January 1931-August 1947), general director delegate;

12. Gérard Tremblay, S.J. (September 1947-August 1949), general director delegate;

13. Friedrich Schwendimann, S.J. (September 1949-September 1971), general director delegate. 